\title{
Benthic microalgae community response to flooding in a tropical salt flat
}

\author{
L. S. M. Masuda ${ }^{a, b *}$ and A. Enrich-Prast ${ }^{a, b, c}$ \\ aPrograma de Pós-graduação em Ciências Biológicas (Microbiologia), Departamento Microbiologia Ambiental, \\ Instituto de Microbiologia Paulo de Góes, Universidade Federal do Rio de Janeiro - UFRJ, \\ Av. Carlos Chagas Filho, 373, Bloco I, Ilha do Fundão, CEP 21941-590, Rio de Janeiro, RJ, Brazil \\ ${ }^{b}$ Laboratório de Biogeoquímica, Instituto de Biologia, Universidade Federal do Rio de Janeiro - UFRJ, \\ Av. Carlos Chagas Filho, 373, Bloco A, Ilha do Fundão, CEP 21941-971, Rio de Janeiro, RJ, Brazil

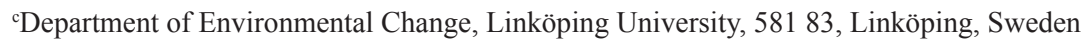 \\ *e-mail: shizuemm@yahoo.com.br
}

Received: August 26, 2014 - Accepted: January 29, 2015 - Distributed: August 31, 2016

(With 2 figures)

\begin{abstract}
This research evaluated the effect of flooding on the microphytobenthos community structure in a microbial mat from a tropical salt flat. Field samples were collected during four consecutive days: on the first three days the salt flat was dry, on the fourth day it was flooded by rain. In order to evaluate the community maintained in flood conditions, samples from this area were collected and kept in the laboratory for 10 days with sea water. The results of total abundance of microphytobenthos varied from $4.2 \times 10^{8}$ to $2.9 \times 10^{9}$ organisms $\mathrm{L}^{-1}$, total density increased one order of magnitude under the effect of water for both situations of precipitation in the salt flat and in experimental conditions, an increase due to the high abundance of Microcoleus spp. Shannon index $\left(H^{\prime}\right)$ was higher during the desiccation period. Our data suggest that changes in the abundance of organisms were due to the effect of water. The dominance of the most abundant taxa remained the same under conditions of desiccation and influence of water, and there is probably a consortium of microorganisms in the microbial mat that helps to maintain these dominances.
\end{abstract}

Keywords: microphytobenthos, cyanobacteria, Microcoleus spp., hypersaline environment.

\section{Resposta da comunidade de microalgas bentônicas à inundação em uma planície hipersalina tropical}

\section{Resumo}

Esse trabalho avaliou os efeitos da inundação na estrutura da comunidade microfitobentônica de um tapete microbiano em uma planície hipersalina tropical. As amostragens foram realizadas no campo durante quatro dias consecutivos: nos três primeiros dias o local estava seco e no quarto dia foi inundando com chuva. Para avaliar a comunidade mantida em condições de inundação, foram coletadas amostras dessa região, sendo mantidas em laboratório por 10 dias com água do mar. Os resultados mostraram que a abundância total do microfitobentos variou de $4.2 \times 10^{8}$ a $2.9 \times 10^{9}$ organismos $\mathrm{L}^{-1}$, a densidade aumentou em uma ordem de grandeza com a influência da água, tanto na planície hipersalina como nas condições experimentais, um aumento que foi devido às maiores abundâncias de Microcoleus spp. O índice de Shannon $\left(H^{\prime}\right)$ foi mais elevado durante o período de dessecação. Nossos dados sugerem que as mudanças na abundância dos organismos foram devidas ao efeito da água, a dominância dos táxons mais abundantes permaneceu a mesma durante as condições de dessecação e inundação, e possivelmente existe um consórcio entre os microrganismos do tapete microbiano no qual eles ajudam a manter essa dominância.

Palavras-chave: microfitobentos, cianobactérias, Microcoleus spp., ambientes hipersalinos.

\section{Introduction}

Benthic microalgae are the main primary producers in tropical salt flats (Stal, 2001; Adame et al., 2012), where hypersaline conditions preclude the presence of most plants. Salt flat benthic communities are usually established in the superficial layers of microbial mats, mostly composed by cyanobacteria and sometimes by a film of diatoms (Stal, 2001; 2012). Many species that

form a cyanobacteria mat in salt flats are well adapted for diazotrophic growth, because this environment is usually N limited (Adame et al., 2012; Stal, 2012).

Microphytobenthic or benthic microalgae from microbial mats are commonly enveloped in exopolimeric substances (EPS), like proteins, nucleic acids, polysaccharides, and other substances, that protect these organisms from desiccation 
and other stress factors in hypersaline environments (Stal, 1995, 2001; Abed and Garcia-Pichel, 2001; Paerl and Yannarell, 2010; Scott and Marcarelli, 2012).

The regulatory salinity effect on microbial mat structure and function has been well established (Pinckney et al., 1995; Stal, 1995, 2001; Paerl and Yannarell, 2010; Hagemann, 2011; Scott and Marcarelli, 2012). Physiological adaptations of cyanobacteria to survive in hypersaline environments are related with specific mechanisms that regulate the osmotic stress internally (Hagemann, 2011). Some of these adaptations are the extrusion of toxic inorganic ions, e.g. high concentration of $\mathrm{Na}^{+}$, and accumulation of organic solutes that protect macromolecules against denaturation and retain hydration. (Hagemann, 2011).

Salt flats are plains where cyanobacteria mats are commonly found and pennate diatoms dominate the sediment surface; these microalgae are adapted to high salinity (Oren, 2012). This environment is submitted to high and fast changes in salinity, owing to the large accumulation of salt, which is a consequence of dry periods after spring tide and high evaporation rates, including salinity reducing rainfall (Zack and Roman-Mas, 1988; Adame et al., 2012). Water is an essential variable related with salinity and it bears direct influence on the microbial mat community, especially in natural events of desiccation (Paerl and Yannarell, 2010; Scott and Marcarelli, 2012). Effects of desiccation and rewetting were tested in benthic communities, and the results demonstrated changes in terms of functions and the composition of bacteria communities. Some studies show that rewetting increases microbial activity (McKew et al.,
2011; Conrad et al., 2014). The goal of this study was to contribute to a better understanding of the desiccation and flooding effects on the cyanobacteria community structure in terms of abundance, diversity and evenness indices in a tropical salt flat environment.

\section{Material and Methods}

\subsection{Study area}

Samples were collected from a salt flat area $\left(23^{\circ} 00^{\prime} \mathrm{S}\right.$ and $43^{\circ} 36^{\prime} \mathrm{W}$ ) in the Guaratiba mangrove (Rio de Janeiro, Brazil, Figure 1). This area is a part of the Sepetiba bay estuary system, and the total Guaratiba mangrove area is $28.3 \mathrm{Km}^{2}$, of which $20.9 \mathrm{Km}^{2}$ comprise mangrove forests and $7.4 \mathrm{Km}^{2}$ comprise salt flats (Estrada et al., 2013). This area is characterized by a small variation in topography and a tidal range below $2 \mathrm{~m}$ (Estrada et al., 2013).

Pellegrini (2000) analyzed the salinity along a transect perpendicular to the sea during the years 1996 to 1998. The average registered in the salt flat varied between 55 and 103 , a variation that was due to the local topography and climate. This salt flat area is usually flooded in the high spring tides and in the regular meteorological tides, while desiccations were associated with low rainfall levels, low tides and high evaporation rates.

According to the Marambaia Meteorological Station, during 2010 and 2011, temperatures ranged from 22 to $35^{\circ} \mathrm{C}$ in the summer, and 17 to $30^{\circ} \mathrm{C}$ in the winter; rainfall was more frequent in the summer than in the winter, with maximum values of 245 and $70 \mathrm{~mm}$, respectively.

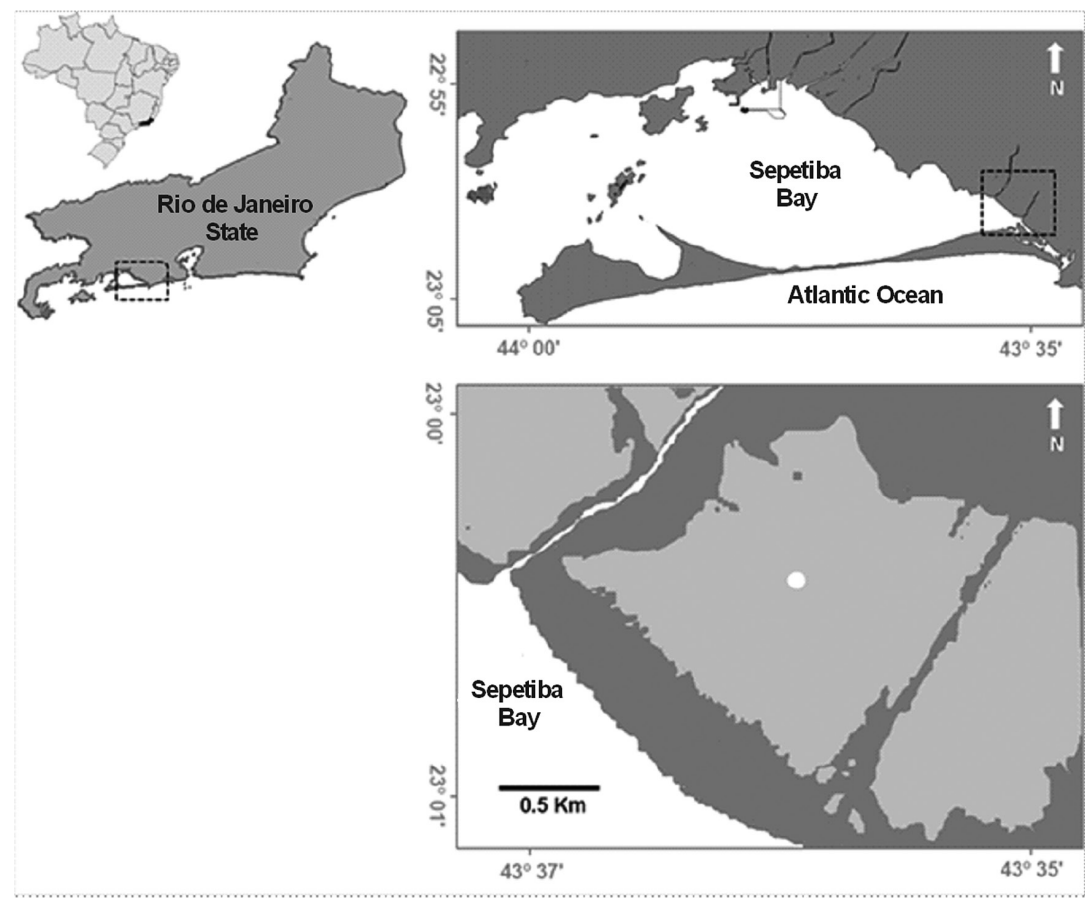

Figure 1. Sampling site location in the Guaratiba salt flat (light gray) surrounded by mangrove forest (dark gray), in Sepetiba Bay, Rio de Janeiro State - Brazil. 


\subsection{Sampling and experimental design}

Single daily samples were collected from the salt flat between July 25 (day 1) and 28 (day 4) 2010, from 08:00am to $08: 30 \mathrm{am}$. The sediment was dry from day 1 to day 3 , but it rained on day 4 and the microbial mat was covered with rainwater at the time of sampling.

In order to evaluate how the community would react to the maintenance of flood conditions, two sediment samples were collected on July 18, 2011, from the same dry sampling site with plexigrass cores and transported to the lab. In the experiment conditions, the microbial mats were kept under oligotrophic marine water in plastic tanks, with added $\mathrm{NaCl}$ to reach a final salinity value of $6 \mathrm{~g} \mathrm{~L}^{-1}$, similar to the salt flat sampling area. The Flooded Experiment (FE) was kept outdoor for 10 days, and these samples were identified as 10-d FE (A) and (B).

In all samples, a plastic core was used to collect the microphytobenthic community. The first $1 \mathrm{~cm}$ of the cores were fixed with a $2 \%$ formaldehyde solution neutralized with hexamethylenetetramine. The community was identified and quantified in Palmer-Malloney chambers $(0.1 \mathrm{~mL})$, using an optical microscope with phase contrast (Olympus BX51). Morphotypes were identified to the lowest level possible according to Anagnostidis and Komárek (1988).
A cyanobacteria trichome was considered as one organism; and in the case of diatoms and dinoflagellates, each cell was counted as one organism. Diversity was calculated using the Shannon index $\left(H^{\prime}\right)$, and evenness was calculated by Pielou's index $\left(J^{\prime}\right)$ (Magurran, 2004).

\section{Results}

July 2010 was marked by low rainfall levels according to the Marambaia Meteorological Station. Prior to the sampling day, rainfall was recorded on July 18 , seven days before the beginning of this study, with $4 \mathrm{~mm}$ to this day; during the sampling period on day 4 (July $28^{\text {th }}$ ) accumulated precipitation reached $38 \mathrm{~mm}$ (from 03:00am to 06:30am).

Microbial mat color changes were observed in the Guaratiba salt flat; during the days that preceded the rain, the microbial mat appearance was that of a dead community, with a dark color which was simultaneously whitened by the salt. Nevertheless, the mat surface changed completely to a greenish color on the rainy day.

The total density of the sediment microalgae community ranged from $4.2 \times 10^{8}$ to $2.9 \times 10^{9}$ organisms $\mathrm{L}^{-1}$. It increased one order of magnitude under the effect of water for both the situation of rainfall in the salt flat and in experimental conditions (Figure 2).

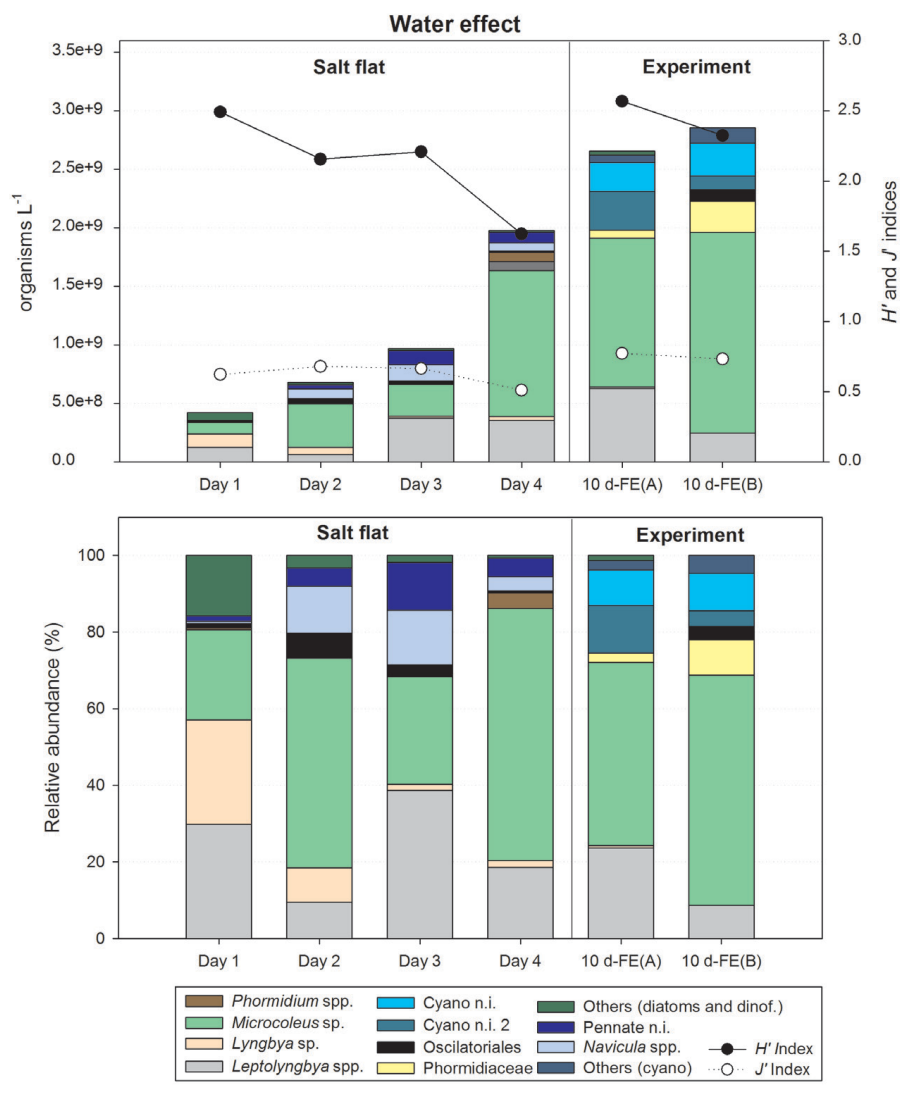

Figure 2. Abundance in organisms $\mathrm{L}^{-1}$, Shannon Index $\left(H^{\prime}\right)$ and Evenness Index $\left(J^{\prime}\right)$, and, relative abundance $(\%)$ of the most abundant taxa in the microbial mat during desiccation and flood periods. Day 1 to day $4=$ salt flat sampling, $10 \mathrm{~d}-\mathrm{FE}=10 \mathrm{days}$ of Flooding Experiment. Others (cyano = cyanobacteria) and Others (diatoms and dinof. $=$ dinoflagellates) were described on Table 1. 
Cyanobacteria from the Oscillatoriales order were the dominant group, especially Microcoleus spp. This taxa varied from $9.9 \times 10^{7}$ (day 1$)$ to $3.7 \times 10^{8}$ (day 2 ) organisms $\mathrm{L}^{-1}$ during the desiccation period on the salt flat, and $1.2 \times 10^{9}$ (day 4) to $1.7 \times 10^{9}(10 \mathrm{~d}-\mathrm{FE}-\mathrm{B})$ organisms $\mathrm{L}^{-1}$ under water effect. The Lyngbya spp. contribution to total density was higher in the salt flat, especially on day, 1 with $1.1 \times 10^{8}$ organisms $\mathrm{L}^{-1}$. Leptolyngbya spp. (Order Pseudanabaenales) ranged from $6.4 \times 10^{7}$ (day 2) to $6.3 \times 10^{8}(10 \mathrm{~d}-\mathrm{FE}-\mathrm{A})$ organisms $\mathrm{L}^{-1}$ (Figure 2). These three taxa together represented 68\% to $80 \%$ of all benthic microalgae (Figure 2 ).

An experimental flooding water effect caused some changes to this community, compared with the salt flat, i.e. Phormidiaceae Class (represented mainly by Microcoleus spp. and Phormidium spp., whose identification on specific level was not possible on the optical microscopic analysis) and filamentous cyanobacteria n.i. (not identified) presented relative abundance between $4 \%$ and $12 \%$ (Figure 2), while in the salt flat were not recorded. Moreover Navicula spp. and pennate diatoms n.i. were no reported in the experiment (Table 1), but in the salt flat their relative abundances reached $14 \%$ and $12 \%$, respectively. Less abundant taxa were grouped in 'Others'. More details on Table 1.

Shannon index $\left(H^{\prime}\right)$ varied between 1.62 (day 4) to 2.49 (day 1 ), and evenness index $\left(J^{\prime}\right)$ ranged from 0.51 (day 4 ) to 0.68 (day 2, Figure 2). $H^{\prime}$ and $J^{\prime}$ indices of the experiment were similar to the salt flat, except for day 4 , highlighting the effect of rainfall water on the community. Species richness was greater on Day 1 with 15 taxa, whereas the other days ranged between 8 and 10 taxa (Table 1).

\section{Discussion}

Benthic microalgae from salt flat microbial mats were dominated by Microcoleus spp., Leptolyngbya spp. and Lyngbya sp. This pattern of dominance was reported by many authors in similar conditions (Paerl et al., 2000; Jonkers et al., 2003; Casillas-Martinez et al., 2005; Eriksson et al., 2010; Adame et al., 2012). Lyngbya, Microcoleus and Phormidium dominances are common in microbial mats classified as polygonal mats; such mats are not consolidated and, during dry periods, they develop polygon shaped wide cracks with upturned and overgrown margins (Eriksson et al., 2010). This was the microbial mat sampled in the Guaratiba salt flat.

Dominance of the most abundant taxa as Microcoleus and Leptolyngbya remained in all analyses, possibly due to the existence of a consortium of microorganisms in the microbial mat, a dominance which was maintained in desiccation conditions and under the influence of water. This consortium is very important for the survival of microalgae in extreme conditions, i.e. desiccation, through the exchange of nutrients and organic compounds among microorganisms such as heterotrophic bacteria and these dominant cyanobacteria. The microbial mat consortium was discussed by other authors as being crucial to community diversification, and enables the co-existence of different organisms with different metabolisms (aerobic and anaerobic) due to physical-chemical gradient, which is accentuated with increased depth (Van Gemerden, 1993; Des Marais, 2010; Stal, 2012). Functional groups are distributed according to

Table 1. Presence (+) and absence (-) of the taxa identified during the desiccation and flood periods of sampling. Day 1 to day 4 = salt flat sampling, $10-\mathrm{d} F E=10$ days of Flooding Experiment.

\begin{tabular}{|c|c|c|c|c|c|c|c|}
\hline \multirow{2}{*}{ Taxa } & \multicolumn{4}{|c|}{ Salt Flat } & \multicolumn{2}{|c|}{ Experiment } & \multirow{2}{*}{ Others } \\
\hline & Day 1 & Day 2 & Day 3 & Day 4 & 10 Days $(A)$ & 10 Days (B) & \\
\hline Leptolyngbya spp. & + & + & + & + & + & + & \\
\hline Lyngbya sp. & + & + & + & + & + & - & \\
\hline Microcoleus sp. & + & + & + & + & + & + & \\
\hline Phormidium sp1 & - & - & - & - & - & + & $*$ \\
\hline Phormidium spp. & + & - & - & + & + & + & $*$ \\
\hline Phormidiaceae & - & - & - & - & + & + & \\
\hline Oscilatoriales & + & + & + & + & - & + & \\
\hline Cyano n.i. 2 & - & - & - & - & + & + & \\
\hline Cyano n.i. & - & - & - & - & + & + & \\
\hline Amphora sp1 & + & - & + & - & - & - & $* *$ \\
\hline Diploneis sp. & + & - & - & - & - & - & $* *$ \\
\hline Navicula spl & + & - & - & - & - & - & $* *$ \\
\hline Navicula $\mathrm{sp} 2$ & + & - & - & - & + & - & $* *$ \\
\hline Navicula spp. & + & + & + & + & - & - & $* *$ \\
\hline Nitzschia spp. & + & + & + & + & - & - & $* *$ \\
\hline Fragilariaceae/ Rhaphoneidaceae & - & - & - & - & + & - & $* *$ \\
\hline Pennate n.i & + & + & + & + & - & - & \\
\hline Coscinodiscus spp. & + & - & - & - & - & - & $* *$ \\
\hline Centric n.i. & + & + & + & - & - & - & $* *$ \\
\hline Thecate n.i. & + & - & + & - & - & - & $* *$ \\
\hline
\end{tabular}

* Others (cyano). ** Others (diatoms and dinoflagellates). 
the need to obtain energy for their vital functions, which in turn is limited by gradients of oxygen, light and sulfide (Van Gemerden, 1993; Des Marais, 2010; Stal, 2012).

Further studies confirmed the importance of the consortium for microalgae, i.e. carbon and/or nitrogen deficient experiments with Chlamydomonas reinhardtii and the nitrogen-fixing bacteria Azobacter revealed decreased chlorophyll content and cell death with 2 months of $C$. reinhardtii monoculture, whereas the Azobacter-Chlamydomonas consortium lasted at least two years (Gyurfán et al., 1986). Watanabe et al. (2005) demonstrated that chlorophyll content from Chlorella sorokiniana decreased after the fifth month, when growth occurred in monoculture; nevertheless, when there was growth in association with the presence of bacteria and fungi, that content remained constant. Those authors discussed the benefits of the consortium based on the availability and consumption of $\mathrm{CO}_{2}$ and $\mathrm{O}_{2}$, just as the fact that bacteria and fungi attached microalgae released mucilage, thereby decreasing the distance of diffusion and increasing the efficiency of nutrient exchange. The prevailing cyanobacteria in this study were species with a mucilage sheath; furthermore, cyanobacteria and diatoms produce a lot of organic matter, which can serve as an energy source to microorganisms. The fact that all these organisms grew in a mat could encouraging exchange of nutrients between them, due to its proximity.

The influence of water was observed in terms of increased density and changes in the composition of less dominant species on the rainy day on the salt flat during the experiment. In dry conditions, water may be a relief to organisms, leading to an increase of populations density. Cyanobacteria migration in the salt flat was observed by changes to sediment color and high density of Microcoleus spp., which resulted in reduced diversity and evenness indices. Typically, the $H^{\prime}$ index and the richness are inversely correlated with the environmental extremity as desiccation (Rothrock Junior and Garcia-Pichel, 2005).

Some studies showed that cyanobacteria are stimulated by water, as they migrate in an opposite direction to desiccation and up to the surface within minutes of the hydration stimulus. They also remain mostly inactive in these desiccated environments, but after a few minutes under moisture they were able to activate photosynthesis and respiration (Garcia-Pichel and Pringault, 2001; Pringault and Garcia-Pichel, 2004). These authors repeatedly tested migration with or without light and without chemical variations, and concluded that the migration response was caused by the water effect. Paerl et al. (2000) also demonstrated the effect of water on desiccated microbial mats; the cyanobacteria community response was fast after hydration, and they start photosynthesis after 30 minutes and $\mathrm{N}$ fixation after few hours.

Salinity changes are a consequence of the influence of water in salt flats. It has been widely discussed in the literature as one of the main factors in structuring the benthic community in microbial mats. Adame et al. (2012) recorded community structure differences across the intertidal zone of the cyanobacteria mat on the salt flat of Giralia Bay (Australia). Pinckney et al. (1995) and Paerl et al. (2000) have concluded that salinity is an influential factor for the composition and functioning of a community. Pinckney et al. (1995) worked with hypersaline ponds in the Bahamas, and revealed different productivity and $\mathrm{N}$ fixation response to osmotic stress, with Scytonema and Microcoleus. Paerl et al. (2000) reviewed three environments, with different physical and stress features, including desiccation, to show differences in the composition and functioning of a community in microbial mats in distinct extreme environments. They suggested that successful reproduction and survival in extreme conditions of radiation, temperature and periodic desiccation occurs as a result of mutualistic relationships among populations within the consortium.

Our data suggest that changes in the abundance of organisms, including changes in the composition of some species, were due to the effect of water, inasmuch as changes occurred after one day on the salt flat and remained for 10 days into the experiment.

\section{Acknowledgements}

We gratefully acknowledge researchers and students in the Biogeochemical Laboratories of the Universidade Federal do Rio de Janeiro (UFRJ). This work was supported by the Brazilian National Council of Technological and Scientific Development (INCT-MAR-COI). Enrich-Prast receives a CNPq Productivity fellowship. Masuda was supported by Ph.D. scholarship from CNPq and the Brazilian Federal Agency for Support and Evaluation of Graduate Education (Capes) for the "Sandwich Ph.D." scholarship.

\section{References}

ABED, R.M.M. and GARCIA-PICHEL, F., 2001. Long-term compositional changes after transplant in a microbial mat cyanobacterial community revealed using a polyphasic approach. Environmental Microbiology, vol. 3, no. 1, pp. 53-62. http:// dx.doi.org/10.1046/j.1462-2920.2001.00159.x. PMid:11225723.

ADAME, M.F., REEF, R., GRINHAM, A., HOLMES, G. and LOVELOCK, C.E., 2012. Nutrient exchange of extensive cyanobacterial mats in an arid subtropical wetland. Marine \& Freshwater Research, vol. 63, no. 5, pp. 457-467. http://dx.doi. org/10.1071/MF11133.

ANAGNOSTIDIS, K. and KOMÁREK, J., 1988. Modern approach to the classification system of cyanophytes. Archiv für Hydrobiologie, vol. 80, pp. 327-472.

CASILLAS-MARTINEZ, L., GONZALEZ, M.L., FUENTESFIGUEROA, Z., CASTRO, C.M., NIEVES-MENDEZ, D., HERNANDEZ, C., RAMIREZ, W., SYTSMA, R.E., PEREZJIMENEZ, J. and VISSCHER, P.T., 2005. Community structure, geochemical characteristics and mineralogy of a hypersaline microbial mat, Cabo Rojo, PR. Geomicrobiology Journal, vol. 22, no. 6, pp. 269-281. http://dx.doi.org/10.1080/01490450500182672.

CONRAD, R., JI, Y., NOLL, M., KLOSE, M., CLAUS, P. and ENRICH-PRAST, A., 2014. Response of the methanogenic 
microbial communities in Amazonian oxbow lake sediments to desiccation stress. Environmental Microbiology, vol. 16, no. 6, pp. 1682-1694. http://dx.doi.org/10.1111/1462-2920.12267. PMid:24118927.

DES MARAIS, D.J., 2010. Marine hypersaline microcoleusdominated cyanobacterial mats in the Saltern at Guerrero Negro, Baja California Sur, Mexico: a system-level perspective. In: J. SECKBACH and A. OREN, eds. Microbial mats. New York: Springer, pp. 403-420.

ERIKSSON, P.G., SARKAR, S., SAMANTA, P., BANERJEE, S., PORAD, H. and CATUNEANU, O., 2010. Paleoenvironmental context of microbial mat-related structures in Siliciclastic Rocks. In: J. SECKBACH and A. OREN, eds. Microbial mats. New York: Springer, pp. 73-108.

ESTRADA, G.C.D., SOARES, M.L.G., CHAVES, F.D.O. and CAVALCANTI, V.F., 2013. Analysis of the structural variability of mangrove forests through the physiographic types approach. Aquatic Botany, vol. 111, pp. 135-143. http://dx.doi.org/10.1016/j. aquabot.2013.06.003.

GARCIA-PICHEL, F. and PRINGAULT, O., 2001. Cyanobacteria track water in desert soils. Nature, vol. 413, no. 6854, pp. 380-381. http://dx.doi.org/10.1038/35096640. PMid:11574875.

VAN GEMERDEN, H., 1993. Microbial mats: a joint venture. Marine Geology, vol. 113, no. 1-2, pp. 3-25. http://dx.doi. org/10.1016/0025-3227(93)90146-M.

GYURFÁN, I., NGHIA, N.H., TÓTH, G., TURTÓZKY, I. and STEFANOVITS, P., 1986. Photosynthesis, Nitrogen fixation and enzyme activities in Chlamydomonas-Azotobacter symbioses. Biochemie und Physiologie der Pflanzen, vol. 181, no. 3, pp. 147-153. http://dx.doi.org/10.1016/S0015-3796(86)80045-2.

HAGEMANN, M., 2011. Molecular biologyof cyanobacterial salt acclimation. Federation of European Microbiological Societies, vol. 35, no. 1, pp. 87-123. PMid:20618868.

JONKERS, H.M., LUDWIG, R., WIT, R., PRINGAULT, O., MUYZER, G., NIEMANN, H., FINKE, N. and BEER, D., 2003. Structural and functional analysis of a microbial mat ecosystem from a unique permanent hypersaline inland lake: "La Salada de Chiprana" (NE Spain). FEMS Microbiology Ecology, vol. 44, no. 2, pp. 175-189. http://dx.doi.org/10.1016/S0168-6496(02)004646. PMid:19719635.

MAGURRAN, A.E., 2004. Measuring biological diversity. Oxford: Blackwell Science.

MCKEW, B.A., TAYLOR, J.D., MCGENITY, T.J. and UNDERWOOD, G.J.C., 2011. Resistance and resilience of benthic biofilm communities from a temperate saltmarsh to desiccation and rewetting. The ISME Journal, vol. 5, no. 1, pp. 30-41. http:// dx.doi.org/10.1038/ismej.2010.91. PMid:20596071.

OREN, A., 2012. Salts and Brines. In: B.A. WHITTON, ed. Ecology of cyanobacteria II. New York: Springer, pp. 401-426.
PAERL, H.W. and YANNARELL, A.C., 2010. Environmental dynamics, community structure and function in a hypersaline microbial mat. In: J. SECKBACH and A. OREN, eds. Microbial mats. New York: Springer, pp. 423-442.

PAERL, H.W., PINCKNEY, J.L. and STEPPE, T.F., 2000. Cyanobacterial-bacterial mat consortia: examining the functional unit of microbial survival and growth in extreme environments. Environmental Microbiology, vol. 2, no. 1, pp. 11-26. http:// dx.doi.org/10.1046/j.1462-2920.2000.00071.x. PMid:11243256.

PELLEGRINI, J.A.D.C. 2000. Caracterização da planície hipersalina (Apicum) associada a um bosque de mangue em Guaratiba, Baía de Sepetiba, Rio de Janeiro - RJ. São Paulo: Universidade de São Paulo. Masters Dissertation.

PINCKNEY, J., PAERL, H.W. and BEBOUT, B.M., 1995. Salinity control of benthic microbial mat community production in a Bahamian hypersaline lagoon. Journal of Experimental Marine Biology and Ecology, vol. 187, no. 2, pp. 223-237. http://dx.doi. org/10.1016/0022-0981(94)00185-G.

PRINGAULT, O. and GARCIA-PICHEL, F., 2004. Hydrotaxis of cyanobacteria in desert crusts. Microbial Ecology, vol. 47, no. 4, pp. 366-373. http://dx.doi.org/10.1007/s00248-002-0107-3. PMid:14605777.

ROTHROCK JUNIOR, M.J. and GARCIA-PICHEL, F., 2005. Microbial diversity of benthic mats along a tidal desiccation gradient. Environmental Microbiology, vol. 7, no. 4, pp. 593-601. http:// dx.doi.org/10.1111/j.1462-2920.2005.00728.x. PMid:15816936.

SCOTT, J.T. and MARCARELLI, A.A., 2012. Cyanobacteria in freshwater benthic environments. In: B.A. WHITTON, ed. Ecology of cyanobacteria II. Dordrecht: Springer, pp. 271-289.

STAL, L.J., 1995. Physiological ecology of cyanobacteria in microbial mats and other communities. The New Phytologist, vol. 131, no. 1, pp. 1-32. http://dx.doi.org/10.1111/j.1469-8137.1995. tb03051.x.

STAL, L.J., 2001. Cyanobacteria mats and stromatolites. In: B.A. WHITTON and M. POTTS, eds. The ecology of cyanobacteria: their diversity in time and space. Dordrecht: Kluwer Academic Publishers, pp. 61-120.

STAL, L.J., 2012. Cyanobacterial mats and stromatolites. In: B.A. WHITTON, ed. Ecology of cyanobacteria II. Dordrecht: Springer, pp. 65-125.

WATANABE, K., TAKIHANA, N., AOYAGI, H., HANADA, S., WATANABE, Y., OHMURA, N., SAIKI, H. and TANAKA, H., 2005. Symbiotic association in Chlorella culture. FEMS Microbiology Ecology, vol. 51, no. 2, pp. 187-196. http://dx.doi. org/10.1016/j.femsec.2004.08.004. PMid:16329867.

ZACK, A. and ROMAN-MAS, A., 1988. Hydrology of the Caribben Island Wetlands. Acta Cientifica, vol. 2, pp. 65-73. 